\title{
Optimizing Weed Control by Integrating the Best Herbicide Rate and Bio-Agents in Wheat Field
}

\author{
Meisam Zargar* ${ }^{1}$, Vadim Plushikov ${ }^{2}$, Elena Pakina ${ }^{1}$, Peter Dokukin and Elena Kalabashkila ${ }^{1}$ \\ ${ }^{1}$ Department of Agro-Biotechnology, Institute of Agriculture, RUDN University, Moscow, 117198, Russia; \\ meisam.za_ir84@yahoo.com \\ ${ }^{2}$ Department of Agro-Engineering, Institute of Agriculture, RUDN University, Moscow, 117198, Russia
}

\begin{abstract}
Cutting of herbicide dosage without compromising grain yield can cause to less environmental pollution and lower production costs. Field experiments were laid out over years 2012 - 2014 to appraise the efficacy of reduced rates of a new generation post-emergence herbicide verdict in combination with biocontrol agent to suppress three major weeds (Chenopodium album, Avena fatua and Capsella bursa-pastoris) in wheat (Triticum aestivum L.) under the condition of Non-chernozem zone, Moscow region. Below labeled rate $0.3 \mathrm{~kg} / \mathrm{ha}^{-1}$ plus bio-agents was quite effective in suppressing total weed populations. This study revealed that a favorable level of weed reduction in wheat fields was obtained when lower herbicide rate $0.3 \mathrm{~kg} / \mathrm{ha} \mathrm{o}^{-1}$ and bio-agents were used, that was comparable to the result which achieved for registered verdict dose as $0.5 \mathrm{~kg} / \mathrm{ha} \mathrm{I}^{-1}$. Hence, despite the higher weed reduction efficacy was obtained with herbicide in registered label dose plus biocontrol agent, but the differences were not significant compared to below herbicide dose $0.3 \mathrm{~kg} / \mathrm{ha}^{-1}$. Meanwhile, the best energy output $\left(90.3 \mathrm{GDj} / \mathrm{ha}^{-1}\right)$, agricultural efficiency $(19.9 \%)$ and wheat grain yield $7.80 \mathrm{t} / \mathrm{ha}^{-1}$ were achieved when reduced herbicide rate $0.3 \mathrm{~kg} / \mathrm{ha} \mathrm{a}^{-1}$ combined to biological agent were applied.
\end{abstract}

Keywords: Weed, Reduced Herbicide Rate, Wheat Yield, Agronomical Efficiency, Energy Output

\section{Introduction}

Herbicides are the dominant tool used for weed management in modern cropping systems; they are highly effective on most weed populations but are not a complete solution to the complex challenge that weeds present. The overuse of herbicides has led to the rapid evolution of herbicide resistance (Beckie 2006; Egan et al., 2011). Herbicides in Labeled doses are often selected to ensure a high level of weed suppression over a wide range of environmental conditions, weed growth stages, and weed species (Blackshaw et al., 2006).

Belles et al. (2000) determined that a 50\% rate of tralkoxydim suppresses more than $85 \%$ of wild oat (Avena fatua L.) in barley field. O'Donovan et al. (2001) also indicated that tralkoxydim at reduced rates can provides an acceptable reduction of wild oat. Study of several herbicides (fluroxypyr; diflufenican plus MCPA and Clopyralid plus 2, 4-D) efficacy in various doses to control broad-leaved weeds in wheat in Iran revealed that the control of Galium tricornutum is above $85 \%$ for the highest herbicide dose, but drops to below $50 \%$ at the lowest dose and these three herbicides used at the highest dose also control Lamium amplexicaule and Descuraina sophia at over $82 \%$ (Zand et al., 2007). Nevertheless, majority of herbicide molecules at lower than- recommended doses are effective enough to provide satisfactory weed control without yield reduction (Walker et al., 2002; Auskalnis and Kadzys, 2006; Barros et al., 2007).

Increasing number of herbicide-resistant weeds (Basu et al., 2004) makes it obvious that frequent use of a single tool for pest control not only leads to a preponderance of the most problematic species, but can basically shift the genetic composition of their populations. However, integrating control practices emphasizes the use of multiple strategies to address the causes of weed fitness, (Buhler 2002). Consequently, investigating for alternative cultural and biological practices has intensified (Hatcher and Melander 2003; Larsen et al., 2004). 
Biological strategies recommended alternatives to the application of chemicals that provide new environmental options weed control practices (Bailey and Mupondwa 2006, Boyetchko 2005). Biological weed control is determined as environment-friendly, utilizing host-specific control components towards weeds that prevent damage to host crops (Pleban and Strobel 1998).

\section{Material and Methods}

Field experiments were conducted on improving the strategies for post-emergence weed suppression in winter wheat (Triticum aestivum) were performed as an intensive farming technology during 2012 - 2014 in the Moscow Research Institute of Agriculture, Moscow area, Russia. The site was located at $55^{\circ} 45^{\prime} \mathrm{N}, 37^{\circ} 37^{\prime} \mathrm{E}$ and $200 \mathrm{~m}$ altitude. Samples were taken randomly from different spots at $0-15 \mathrm{~cm}$ to record the initial characteristics of the experimental soil.

\subsection{Field Layouts Details}

Biological agents [bio-herbicide, bio-fertilize and bio-fungicide with anti stress activity to weather conditions and chemical treatments in combination with the various rates of new generation post-emergence herbicide 'verdict' $(0,0.2,0.3$ and $0.5 \mathrm{~kg} / \mathrm{ha}-1)$ adjuvant $0.5 \mathrm{~L} / \mathrm{ha}-1$ was mixed to herbicide as a tank mix. All agents were used at the early stem stage of wheat, and, other cultural practices were typical of those used for commercial winter wheat production in Moscow region.

Variety of wheat cv. Moscovskaya 39 was sown in August 2012 and in the second and third year the same variety was sown in September 2013 and 2014, using densities of 5 million viable seeds per hectare. Formulation of herbicide verdict: meso-sulfuron-methyl $30 \mathrm{~g} / \mathrm{kg}$, iodine-sulfuron-methyl -sodium $6 \mathrm{~g} / \mathrm{kg}$ and mefenpir -diethyl $90 \mathrm{~g} / \mathrm{kg}$. Bioherbicide Kemi: is a biological herbicide contains the microorganism Colletotrichum spp. Mentioned bioherbicide can be used mid and late season when most chemicals cannot be sprayed, the usual rate $3 \mathrm{~kg} / \mathrm{ha}^{-1}$. Biofertilizer Humi: is a humic fertilizer, contains humic acid and such ingredients as $\mathrm{B}, \mathrm{Mo}, \mathrm{Co}, \mathrm{Cu}, \mathrm{S}, \mathrm{I}, \mathrm{Mn}, \mathrm{Zn}$, this agent helps plants survive stress caused by weather conditions and chemical treatments. It also reduces the incidence of damage by pests and diseases and increases the yield; it can be applied at the rate of $1 \mathrm{~L} / \mathrm{ha}^{-1}$. Phytosporin is a bio-fungicide with anti stress activity to weather conditions and chemical and growth regulator activity, consisting of highly active spores of endophyte bacterium Baccilus subtilis. It is effective against a wide range of fungal and bacterial diseases. For winter wheat $1 \mathrm{~L} / \mathrm{ha}^{-1}$ during tillering stage can be used.

\subsection{Data Analysis}

Weed density from $0.25 \mathrm{~m}^{2}$ area of each net plot was counted each year at 30 days after treatments by the use of $50 \times 50 \mathrm{~cm}^{2}$ quadrate according to the method of European Weed Research Society. The whole weeds were dried in an oven at $70^{\circ} \mathrm{C}$ until constant weight was achieved for dry weight factor. Chenopodium album, Capsella bursa-pastoris and Avena fatua were as determined species for this study.

Analysis of variance (ANOVA) was used to assess the variation of the data. Duncan's multiple range tests at $\mathrm{P}, 0.05$ was used to compare the means and determine the significance of differences between variables using SAS (SAS institute, 2002) for Windows.

\section{Result and Discussion}

\subsection{Weed Control Efficacy during 2013 - 2014}

The higher efficacy was obtained with the maximum herbicide dose $0.5 \mathrm{~kg} / \mathrm{ha}^{-1}$ plus bio-agents, but the difference was not high compared to the verdict dose $0.3 \mathrm{~kg} / \mathrm{ha}^{-1}$. Additionally, the lowest herbicide rate 0.2 $\mathrm{kg} / \mathrm{ha}^{-1}$ combined with bio-agents had a significantly lowest control efficacy on declining of weed species: Cenopodium album, Capesella bursa-pastoris and Avena fatua. Although the highest weed control was achieved with the labeled dose of verdict $\left(0.5 \mathrm{~kg} / \mathrm{ha}^{-1}\right)$, intermediate herbicide dose $0.3 \mathrm{~kg} / \mathrm{ha}^{-1}+$ bio-agents also provided a desirable reduction about all three weeds varieties (Figure 1,2). Hence, below registered dose of herbicide could be used as a cost effective, economical and environmentally friendly approach to minimize weed pressure in crop fields. As in our study, the efficacy of cutting rates of herbicide groups has been determined by other authors (Barros et al. 2009; Barros et al. 2011; Kieloch and Domaradzki 2011; Buczek et al. 2012). 
According to the results of this study, despite the highest weeds control efficacy was obtained with the registered dose of herbicide, below-labeled rate $0.3 \mathrm{~kg} / \mathrm{ha}^{-1}$ plus biological agents also caused acceptable weed reduction about entire weeds varieties (Figure 1,2). There are examples where herbicides are used at doses that do not often cause such high weed suppression. Indeed, using herbicide rates can vary markedly between countries and enterprises. For instant, doses of herbicide in Australia are often 50\% of that in other nations.

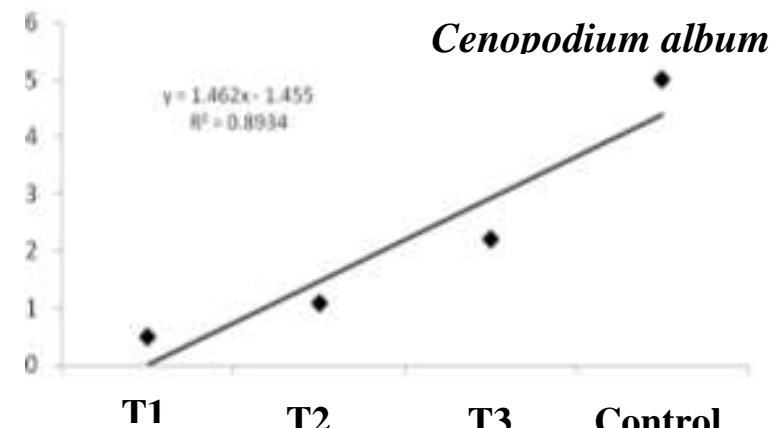

Avena fatua

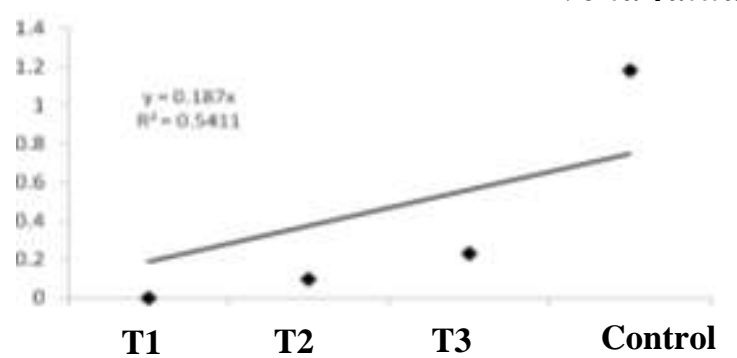

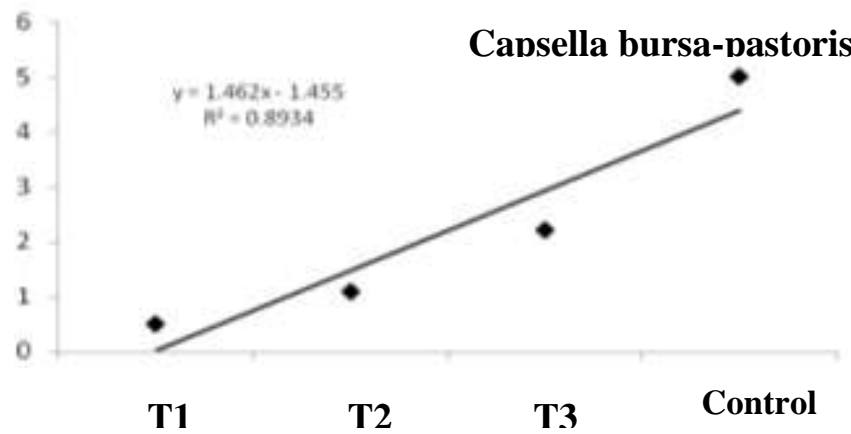

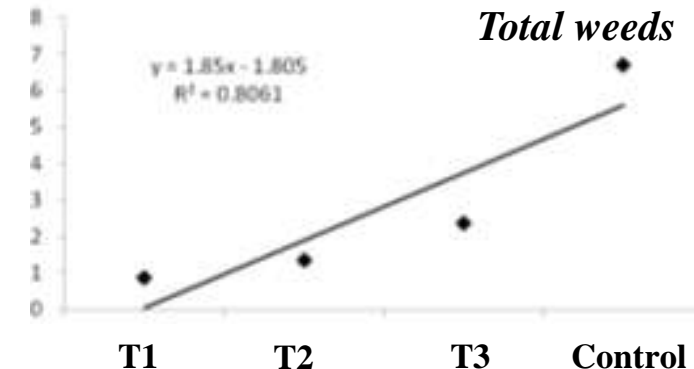

Fig 1 . Weed dry weight affected by treatments 30 days after applications in $2013\left(\mathrm{plant} / \mathrm{m}^{-2}\right)$.

Abbreviations: T1, T2, T3 are herbicide dose 0.5, 0.3 and $0.2 \mathrm{~L}^{-1} \mathrm{~h}^{-1}$ respectively plus bio-agents.
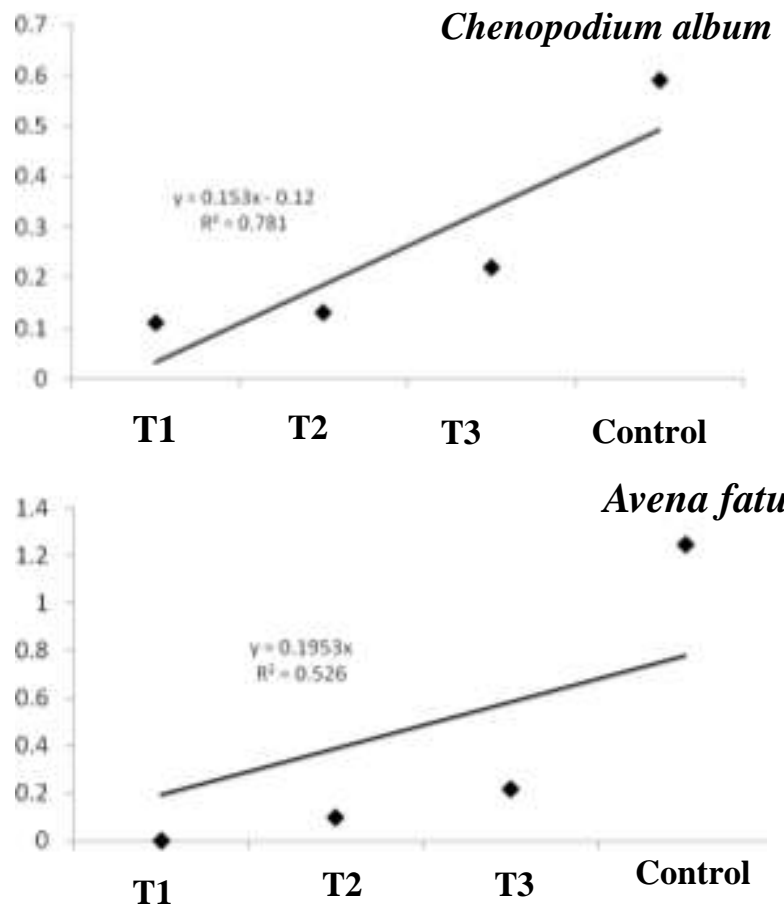
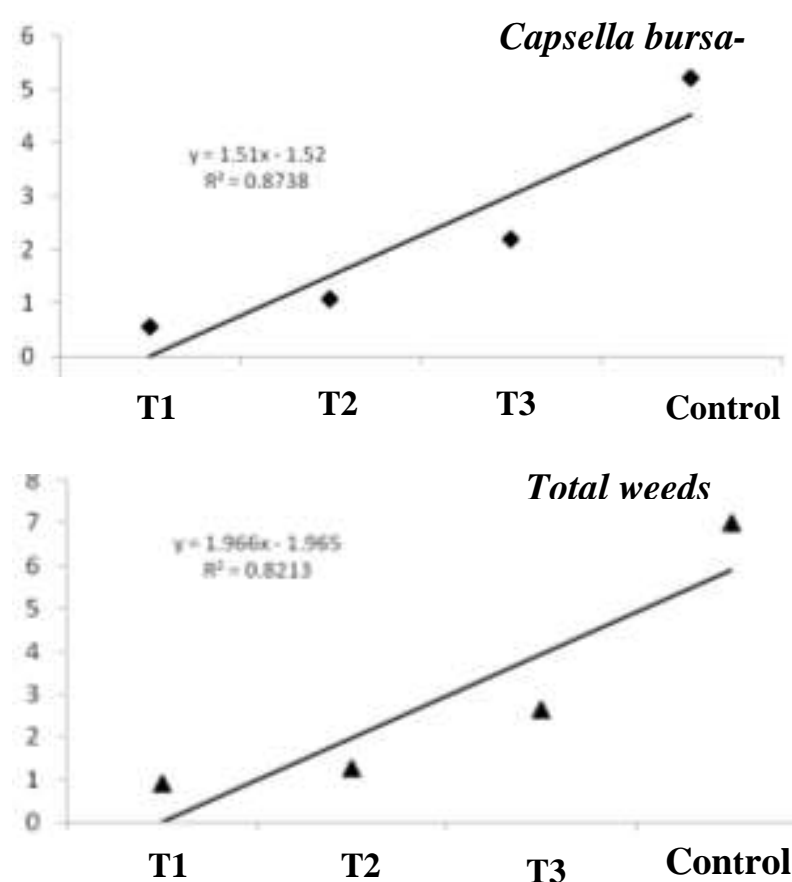

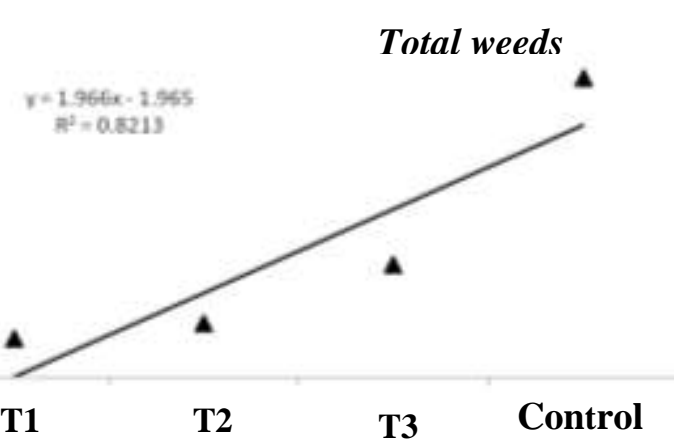

Fig 2. Weed dry weight affected by treatments 30 days after applications in $2014\left(\mathrm{plant} / \mathrm{m}^{-2}\right)$. Abbreviations: T1, T2, T3

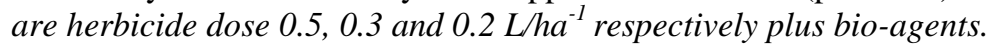


However, the labeled rate for diclofop in Australia is $375 \mathrm{~g}$ ai ha21 compared with $640 \mathrm{~g}$ ai ha21 in the United States and $900 \mathrm{~g}$ ai ha21 in France (Bayer 2010). Moreover, 28\% of the crop fields in Canada manage weeds with reduced dose of herbicides (Beckie 2006). In addition to dose cutting, environmental variability under field conditions for soil residual herbicides can result in lower than- normal doses of herbicides being used to weed populations (Zhang et al., 2000).

Biological agents cannot replace chemicals, or any other weed control tools, hence, biological agents should be combined to other control techniques (Medd et al., 2001).

\subsection{Biological Efficiency of Treatments during 2013 - 2014}

Estimating the biological efficiency of verdict combined to bio-agents 30 days after application demonstrated that herbicide $0.5 \mathrm{~kg} / \mathrm{ha}^{-1}$ combined to bio-agents reduced weeds dry weight $90-91 \%$ and density 86.6 - 87.5\% compared to the control during 2013 - 2014 experimental years, additionally, dry weight and density of weeds were desirably declined in comparison with control when bellow labeled herbicide rate 0.3 $\mathrm{kg} / \mathrm{ha}^{-1}$ was used (Table 1 ).

According to the result, it can be recommended to reduce herbicide rates combined to biocontrol agents in order to improve weed control programs, this point in addition to control weeds in a proper way can diminish environmental pollution, herbicide resistant weeds and ultimately achieve sustainable agricultural system. Some investigations have demonstrated satisfactory weed reduction and also acceptable yields, while herbicides are applied at lower than registered rates (Bostrom and Fogelfors, 2002).

Results of this study might be due to the integration of biological agent to herbicide. It is necessary to realize that a bioherbicide or any biological weed control techniques are not an analogue of a chemical. Nevertheless, bioherbicides or any other biological practices have to be combined to other control tools in an integrated weed management approach. In this regards, recent studies have illustrated that low rates of herbicides could result in faster evolution of herbicide-resistant weed (Manalil et al., 2011). So, reducing herbicide rate is better combined to integrated techniques.

TABLE I: Biological Efficiency of Treatments 30 Days after Applications during 2013 -2014.

\begin{tabular}{cccccc}
\hline Treatments & Yr & $\begin{array}{c}\text { Density } \\
\text { plant/M }^{-2}\end{array}$ & $\begin{array}{c}\text { Dry weight } \\
\text { gr/m } \text { - }^{-2}\end{array}$ & $\begin{array}{c}\text { Percent of weed reduction compared to control } \\
\text { Density }\end{array}$ \\
\hline \multirow{2}{*}{ T 1 } & 2013 & 7.5 & 0.6 & 87.5 & 91 \\
& 2014 & 8 & 0.7 & 86.6 & 90 \\
T 2 & 2013 & 13 & 1.3 & 79 & 82 \\
& 2014 & 13 & 1.2 & 78.3 & 83 \\
T 3 & 2013 & 27 & 2.3 & 55 & 65.6 \\
& 2014 & 25 & 2.6 & 58 & 62.5 \\
T 4 & 2013 & 60 & 6.7 & - & - \\
& 2014 & 60 & 7 & - & - \\
\hline
\end{tabular}

Abbreviations: T1, T2, T3 and T4 are herbicide dose 0.5, 0.3, $0.2 \mathrm{~L}^{-1} \mathrm{a}^{-1}$ plus bio-agents and control respectively.

Energetic efficiency. Energetic efficiency is an important factor for sustainability of the cropping systems, hence, effective energy use allows financial savings (Pervanchon et al., 2002) and can lead to environmentfriendly production systems (Gundogmus and Bayramoglu, 2006). For the mentioned reason, energy input and output are essential index to specify the energetic efficiency of crop productions (Rathke and Diepenbrock, 2006). In this study, the best energy output was obtained $\left(90.3 \mathrm{GDj} / \mathrm{ha}^{-1}\right)$ when intermediate verdict rate 0.3 $\mathrm{kg} / \mathrm{ha}^{-1}$ combined to biological components were used (Table 4). 
TABLE IV: Energetic efficiency in winter wheat (Maskovskaya 39) variety, average for three yrs 2012 2014).

\begin{tabular}{lcccc}
\hline Treatments & Yield, t/ha & Energy output, GDj/ha ${ }^{-1}$ & Cost, GDj/ha & Energetic efficiency rate \\
\hline T 1 & 6.97 & 85.0 & 10.0 & 1.7 \\
T 2 & 7.40 & $\mathbf{9 0 . 3}$ & 10.7 & 1.8 \\
T 3 & 6.83 & 83.3 & 9.8 & 1.7 \\
T 4 & 6.17 & 75.3 & 8.9 & 1.8 \\
Abbreviations: & T1, T2, T3 and T4 are herbicide dose $0.5,0.3,0.2$ L/ha $^{-1}$ plus bio-agents and control \\
respectively. & & &
\end{tabular}

\section{References}

[1] A. Auskalnis and A. Kadzys, 2006. Effect of timing and dosage in herbicide application on weed biomass in spring wheat. Agronomy Research 4:133-136.

[2] Bayer, 2010. Bayer crop science. http://www.bayercropscience.com. Accessed: January 10, 2010.

[3] C. Basu, M. D. Halfill, T. C. Mueller and C. N. J. Stewart, 2004. Weed genomics: new tool to understand weed biology. Trends Plant Sci. 9:391-398. https://doi.org/10.1016/j.tplants.2004.06.003

[4] D. S. Belles, D. C. Thill and B. Shafi, 2000. PP-604 rate and Avena fatua density effects on seed production and viability in Hordeum vulgare. Weed Science 48:378-384. https://doi.org/10.1614/0043-1745(2000)048[0378:PRAAFD]2.0.CO;2

[5] D. D. Buhler, 2002. Challenges and opportunities for integrated weed management. Weed Sci. 50:273-280. https://doi.org/10.1614/0043-1745(2002)050[0273:AIAAOF]2.0.CO;2

[6] E. Gundogmus, Z. Bayramoglu, 2006. Energy input use on organic farming: a comparative analysis of organic versus conventional farm in Turkey. Journal of Agronomy 5 (1), 16-22. https://doi.org/10.3923/ja.2006.16.22

[7] E. Zand, A. B. Mohammad, S. Saeid, P. A. Reza, V. Mozhgan, B. Alireza and N. Nooshin, 2007. Broadleaved weed control in winter wheat (Triticum aestivum L.) with post-emergence herbicides in Iran. Crop Prot 26, 746-752. https://doi.org/10.1016/j.cropro.2006.06.014

[8] F. Pervanchon, C. Bockestaler and P. Girardin, 2002. Assessment of energy use in arable farming systems by means of an agro-ecological indicator: the energy indicator. Agricultural Systems 72, 149-172. https://doi.org/10.1016/S0308-521X(01)00073-7

[9] G. W. Rathke, T. Behrens, W. Diepenbrock, 2006. Integrated nitrogen management strategies to improve seed yield, oil content and nitrogen efficiency of winter oilseed rape (Brassica napus L.): A review. Agriculture, Ecosystems and Environment 117, 80-108. https://doi.org/10.1016/j.agee.2006.04.006

[10] H. J. Beckie, 2006. Herbicide-resistant weeds: management tactics and practices. Weed Technol. 20:793-814. https://doi.org/10.1614/WT-05-084R1.1

[11] J. F. C. Barros, G. Basch and M. Carvalho, 2007. Effect of reduced doses of a post-emergence herbicide to control grass and broadleaved weeds in no-till wheat under Mediterranean conditions. Crop Protection 26:1538-1545. https://doi.org/10.1016/j.cropro.2006.12.017

[12] J. F. C. Barros, G. Basch, R. Freixial and M. Carvalho, 2009. Effect of reduced doses of mesosulfuron + iodosulfuron to control weeds in no-till wheat under Mediterranean conditions. Spanish Journal of Agricultural Research 7 (4): 905-912. https://doi.org/10.5424/sjar/2009074-1104

[13] J. C. Barros, G. Basch, J. G. Calado, M. Carvalho, 2011. Reduced doses of herbicides to control weeds in barley crops under temperate climate conditions. Revista Brasileira Ciências Agrárias Recife 6 (2): 197-202. https://doi.org/10.5039/agraria.v6i2a814

[14] J. F. Egan, B. D. Maxwell, D. A. Mortensen, M. R. Ryan and R. G. Smith, 2011. 2, 4 dichlorophenoxyacetic acid (2, 4D)-resistant Q:1 crops and the potential for evolution of 2, 4 D-resistant weeds. Proc. Natl. Acad. Sci. USA 108 E37; published ahead of print March 3, 2011. DOI: 10.1073/pnas. 1017414108. https://doi.org/10.1073/pnas

[15] J. Buczek, E. Szpunar-Krok, R. Tobiasz-Salach, D. Bobrecka-Jamro, 2012. Influence of sowing density and dose tribenuronmetyl on weed infestation in spring wheat. Progress of Plant Protection/Postępy w Ochronie Roślin 52 (1): $62-66$. 
[16] J. T. O’Donovan, K. N. Harker, G. W. Clayton, J. C. Newman, D. Robinson and L. M. Hall. Barley seeding rate influences the effects of variable herbicide rates on wild oat. Weed Science, v.49, n.6, p.746-754, 2001. https://doi.org/10.1614/0043-1745(2001)049[0746:BSRITE]2.0.CO;2

[17] J. Zhang, S. E. Weaver and A. S. Hammil, 2000. Risks and reliability of using herbicides at below-labeled doses. Weed Technol 14, 106-115. https://doi.org/10.1614/0890-037X(2000)014[0106:RAROUH]2.0.CO;2

[18] K. L. Bailey and E. K. Mupondwa, 2006. Developing microbial weed control products: commercial, biological, and technological considerations. Pages 431-473 In: H. P. Singh, D. R. Batish, and R. K. Kohli (eds.), Handbook of Sustainable Weed Management. The Haworth Press Inc., Binghamton, NY.

[19] R. E. Blackshaw, J. T. O’Donovan, K. N. Harker, G. W. Clayton, R. N. Stugard, 2006. Reduced herbicide doses in field crops: A review. Weed Biol. Manag. 6, 10-17. https://doi.org/10.1111/j.1445-6664.2006.00190.x

[20] R. Kieloch and K. Domaradzki, 2011. The role of the growth stage of weeds in their response to reduced herbicide doses. Acta Agrobotanica 64 (4): 259-266. https://doi.org/10.5586/aa.2011.068

[21] R. W. Medd, J. Van de Den, D. I. Pickering and T. Nordblom, 2001. Determination of environment-specific doseresponse relationships for clodinafop-propargyl on Avena spp. Weed Res. 41, 351-368. https://doi.org/10.1046/j.1365-3180.2001.00243.x

[22] S. M. Boyetchko, 2005. Biological herbicides in the future. Pages 29-47 In: J. A. Ivany (ed). Weed Management in Transition. Topics in Canadian Weed Science (Vol. 2). Sainte-Anne-de-Bellevue, Quebec. Canadian Weed Science Society - Societe canadienne de malherbologie.

[23] S. U. Larsen, P. Kristoffersen and J. Fischer, 2004. Turfgrass management and weed control without pesticides on football pitches in Denmark. Pest Manag. Sci. 50:579-587. https://doi.org/10.1002/ps.845

[24] S. Manalil, R. Busi and S. B. Powles, 2011. Rapid evolution of herbicide resistance by low herbicide dosages. Weed Sci. 59, $210 \mathrm{e} 217$.

[25] S. Pleban and G. A. Strobel, 1998. Rapid evaluation of Fusarium spp. as a potential biocontrol agent for weeds. Weed Sci. 46, 703-706.

[26] SAS institute, 2002. The SAS system for windows, release 9.1. The Institute Cary, NC, USA.

[27] S. R. Walker, R. W. Med, G. R. Robinson, B. R. Cullis, 2002. Improved management of Avena ludoviciana and Phalaris paradoxa with more densely sown wheat and less herbicide. Weed Res 42, 257-270. https://doi.org/10.1046/j.1365-3180.2002.00283.x

[28] U. BOSTRÖM and H. FOGELFORS, 2002. Response of weeds and crop yield to herbicide dose decision - support guidelines. Weed Sci 50, 186-195. https://doi.org/10.1614/0043-1745(2002)050[0186:ROWACY]2.0.CO;2 